\title{
Predator-Proof Bomas as a Tool in Mitigating Human-Predator Conflict in Loitokitok Sub-County, Amboseli Region of Kenya
}

\author{
David Owino Manoa ${ }^{*}$, Francis Mwaura² \\ ${ }^{1}$ Born Free Foundation, Nairobi, Kenya \\ ${ }^{2}$ Department of Geography \& Environmental Studies, University of Nairobi, Nairobi, Kenya \\ Email: *davidmanoa@me.com
}

Received 24 November 2015; accepted 11 January 2016; published 14 January 2016

Copyright (C) 2016 by authors and Scientific Research Publishing Inc.

This work is licensed under the Creative Commons Attribution International License (CC BY). http://creativecommons.org/licenses/by/4.0/

\section{(c) (i) Open Access}

\section{Abstract}

Human-wildlife conflict (HWC) arises when wildlife shares the same physical space with humans. HWC, particularly livestock predation results in great negative impacts both to pastoralist and carnivores. Various approaches including compensation, livestock guarding, translocation of the problematic predator, and predator-proof bomas (PPB) have been used to mitigate such conflicts. We assessed PPB in mitigating human-predator conflict in Loitokitok sub-county by focusing on its effectiveness, most problematic predator, community's perceptions, and comparing the PPB and traditional bomas characteristics. Data were obtained from $\mathbf{9 0}$ homesteads in Olgulului, Mbirikani and Kimana/Tikondo group ranches. Correlation and paired t-tests were used to analyze the data. Our findings suggest that the boma sizes correlated with the total number of livestock in the boma $(r=0.386, n=90, p=0.000)$ but not the number of people. Hyena and lion accounted for the highest loss of shoats and cattle, with hyena mostly killing shoats $(37 \%)$ and lions preying largely on cattle $(34 \%)$. The most problematic predator was as hyena $(68 \%)$. We found positive relationships between the most problematic predator and total number of livestock $(r=0.319, n=90, p=0.002)$, and boma circumference $(r=0.295, n=90, p=$ 0.005). Livestock predation was high in boma during the wet seasons (April, September, October and December). The erection of PPB reduced livestock predation by $91.11 \%(n=45)$ and time spend guarding livestock at night. We recommend a continuous maintenance of the PPB as a long term solution to livestock loss at night and a close guarding of livestock during the day by adults to reduce day time predations.

\footnotetext{
*Corresponding author.
}

How to cite this paper: Manoa, D.O. and Mwaura, F. (2016) Predator-Proof Bomas as a Tool in Mitigating Human-Predator Conflict in Loitokitok Sub-County, Amboseli Region of Kenya. Natural Resources, 7, 28-39. 


\section{Keywords}

\section{Livestock, Predators, Predator-Proof Boma, Human-Wildlife Conflict}

\section{Introduction}

Human-wildlife conflict (HWC) arises when wildlife shares the same physical space with humans. According to [1], HWC is a "contentious issue" that negatively impacts on the local resident's socio-economic dimensions, while at the same time wildlife species are legally protected both nationally and internationally. Historically, HWC has been in existence since the dawn of humankind. For example, [2] affirmed that the first hominids fell prey to the animals with which they shared their habitats and shelters. In modern times, HWC can be "real or perceived, economic or aesthetic, social or political" [3]. HWC has been considered as a global problem occurring both in developed and developing world [4] [5]. The conflict is rapidly becoming a key issue to the wildlife conservationist and managers with increased interest by more people to actively participate in wildlife management decisions [6].

HWC involves a wide range of occurrence environments and species from the grain poaching rodents to the man eating tigers (Panthera tigris) of the world [7]. For instance, in the Sanjiangyuan region of China, the brown bears are reported to raid villages and damage foods stores and kill sheep. It is estimated that the cost of addressing the damages ranges from $\$ 700$ to $\$ 2800$, which exceeds most family's annual income [8]. In the United States of America (USA), [9] found out that vehicle collisions with the white-tailed deer (Odocoileus virginianus) were injuring upto 29,000 people and damaging properties worthy more than $\$ 1$ billion annually in rural counties. In Manitoba Canada, conflict between elk (Cervus elaphus) and the farmers had been documented since 1880. However, the creation of the Riding Mountain National Park in 1930 and a ban in hunting increased the elk population and intensified elk-farmers conflicts. Elks damage fences and crops estimated to be over \$24,000 annually and they are also associated with the spread of bovine tuberculosis to dairy cattle [10].

In Africa, most countries still hold a considerable number of wildlife, and HWC is very high. This has been attributed to the poverty, defective institutions, and over-reliance of people on natural resources, which increases their contact with wildlife. Studies have shown that some communities in Africa lose up to $10 \%-15 \%$ of their agricultural produce to elephants, a figure which might seem low nationally, but very significant to individual families [11]. Wildlife also kills and injures people, for example, in Cabo Delgado province of Mozambique, where 70 people were killed by elephants in 2001-2002 while protecting their crops at night, while in Tanzania, 28 people were killed and 57 other injured by crocodiles between 1999-2004.

The Kenya wildlife heritage is a key asset for the tourism sector which accounts for about $10 \%$ of the Gross Domestic Product (GDP), making it the third largest contributor to the GDP after agriculture and manufacturing. Wildlife tourism is occasionally the leading foreign exchange earner in Kenya, generating upto Ksh 75.2 billion (about US $\$ 1$ billion) per year. The tourism sector accounts for about $9 \%$ of total formal employment in the country. Studies have previously established that approximately $70 \%$ of the gross tourism earnings in Kenya and $5 \%$ of total GDP can be attributed to the spectacular wildlife heritage in the country. Consequently, one of the key goals of Kenya Vision 2030 is to ensure that the wildlife heritage is protected and the annual revenue from the tourism sector is increased to about Ksh 180 billion. The establishment of wildlife heritage conservation areas in Kenya during the colonial times marked a major departure from communal or customary ownership of wildlife heritage to the state property regime. Since then, many wildlife heritage conservation areas have been surrounded by hostile people who have no sympathy for the wildlife which they consider as government property. This has also led to a wide range of HWC challenges. Between 2000 and 2007, for example, over 200 people were reported to have been killed by elephants in Kenya [12].

Kenya Wildlife Service (KWS), the Kenya's state agency mandated to protect and conserve wildlife, together with other conservation stakeholders have introduced a number of HWC mitigation strategies to reduce the tension between people and wildlife. The most common are compensation scheme for livestock killed by carnivores, lion monitoring to alert the herds and evade lion areas, land zoning for wildlife and grazing, lion lights installation and predator-proof bomas. A boma is a Kiswahili term for a livestock or household compound enclosing structure. 
The aim of this study was to evaluate the use of predator-proof bomas (PPB) as a HWC mitigation strategy in three community group ranches within the Amboseli region, namely Olgulului, Imbirikani and Kimana/Tikondo. The study was designed to fill up the identified gaps in the project so as to help inform future replications and designs by implementing organizations. In addition, there is an increasing pressure from the donors for "evidence" and hence the need for evidence-based conservation. The evidence is essential in measuring the effects of such projects and therefore providing a basis upon which donors, beneficiaries, researchers and the implementing organizations can replicate the project in other areas experiencing similar problems. [13] and [14] asserts that the effectiveness of conservation interventions in reducing conflicts has not always been adequately assessed. According to [15], while considerable effort has been made to mitigate human-wildlife conflict, the evaluation of the success or failure of such interventions, has lagged behind. [16] also emphasized that judging the effectiveness of conservation interventions in different contexts is absolutely essential to ensuring that overstretched and scarce conservation funds go as far as possible in achieving conservation outcomes. Little has been done regarding the assessment of the predator-proof boma in mitigating conflict in Amboseli except for the study by [17] which dwelled on the human-carnivore conflict in Elerai and Olitiyiani conservancies. No studies had been conducted to assess the predator-proof bomas as a tool for mitigating conflict with carnivores in the livestock-dominated group ranches around Amboseli National Park. The specific objectives of the study were to: a) establish the most problematic predator on livestock attacks in the Amboseli group ranches and assess the local community's attitude towards the main problematic carnivores, b) describe the community opinions on the effectiveness of the predator-proof barrier in mitigating livestock predation, c) assess the perceived social-economic benefits of predator-proof barriers to the beneficiary households and compare traditional bomas and predator-proof bomas characteristics.

\section{Methodology}

The Amboseli ecosystem is located in the Loitokitok sub-county on the boarder of Kenya and Tanzania. The sub-county is located at the southern end of the Kajiado County between longitudes $36^{\circ} 5^{\prime}$ and $37^{\circ} 55^{\prime}$ East and between latitude $1^{\circ} 10^{\prime}$ and $3^{\circ} 10^{\prime}$ South [18]. The Amboseli ecosystem comprises of six group ranches: Olgulului, Kimana/Tikondo, Kuku, Rombo and Eselenkei which cover an area of about 506,329 hectares (Figure 1) [19]. The ecosystem is a semi-arid characterized by a warm and dry climate [20], and receives a bimodal rainfall pattern, with short rains between October and December, and the long rains between March and May. The annual mean rainfall ranges from 500 - $600 \mathrm{~mm}$ while the annual average temperature is $18.9^{\circ} \mathrm{C}$ [21]. The main vegetation type species are Acacia, Commiphora and Balanites spp. species, while the dominant grass is Pennisetum and Chloris guyana species [21]. The sub-county is rich in natural endowment with range of wildlife species such as elephants, buffalo, Zebra, cheetah, hyena, lions, wildebeests, giraffes, elands among others [21]. The Amboseli ecosystem is estimated to have $64 \pm 20.96$ lions, $272 \pm 59.31$ hyena and $25.56 \pm 3.53$ jackals [19], with over 400 species of birds [22]. Pastoralism is the main economic activity with over $75 \%$ of the population deriving their livelihood from livestock which accounts for 60\% of the total labour force [17] [21]. About 31\% practice both livestock keeping and crop cultivation, 22\% practice crop farming only, 2\% are employed and 1\% rely on small scale business [17].

The PPB project in the study area entails upgrading the traditional Maasai manyatta by adding posts, rolls of chain-links and flattened oil drum doors. In March 2015, a total of 175 traditional Maasai bomas had been upgraded to "Predator-Proof" status both in Amboseli-Tsavo ecosystem in Kenya and West Kilimanjaro in Tanzania. The project is implemented on a cost sharing basis, with community members contributing 25\% of the material and operation costs [23]. The project focuses on livestock predation at night and intend to change the perception of the beneficiaries of the project and encourage others to adopt the PPB. However, livestock predation in the field while grazing is likely to negatively influence the community attitudes to the project and the predators. There is also the question of whether the PPB are "diverting” predators to the traditional bomas (unfenced) or not. This study was conducted between $29^{\text {th }}$ April and $8^{\text {th }}$ May 2015, and the study area comprised of six key clusters, namely: Imbirikani group ranch (MGR), Olgulului group ranch (OGR), Eselenkei group ranch (EGR), Kuku/Rombo group ranch (K/RGR), Enduimet and Kimana/Tikondo (KGR/Tikondo) with 175 predator-proof bomas which formed the target population.

The latest map of predator-proof bomas location and a list of their respective GPS were obtained from the Born Free Foundation. Although, the entire Amboseli-West Kilimanjaro region had a total of 175 predator-proof 


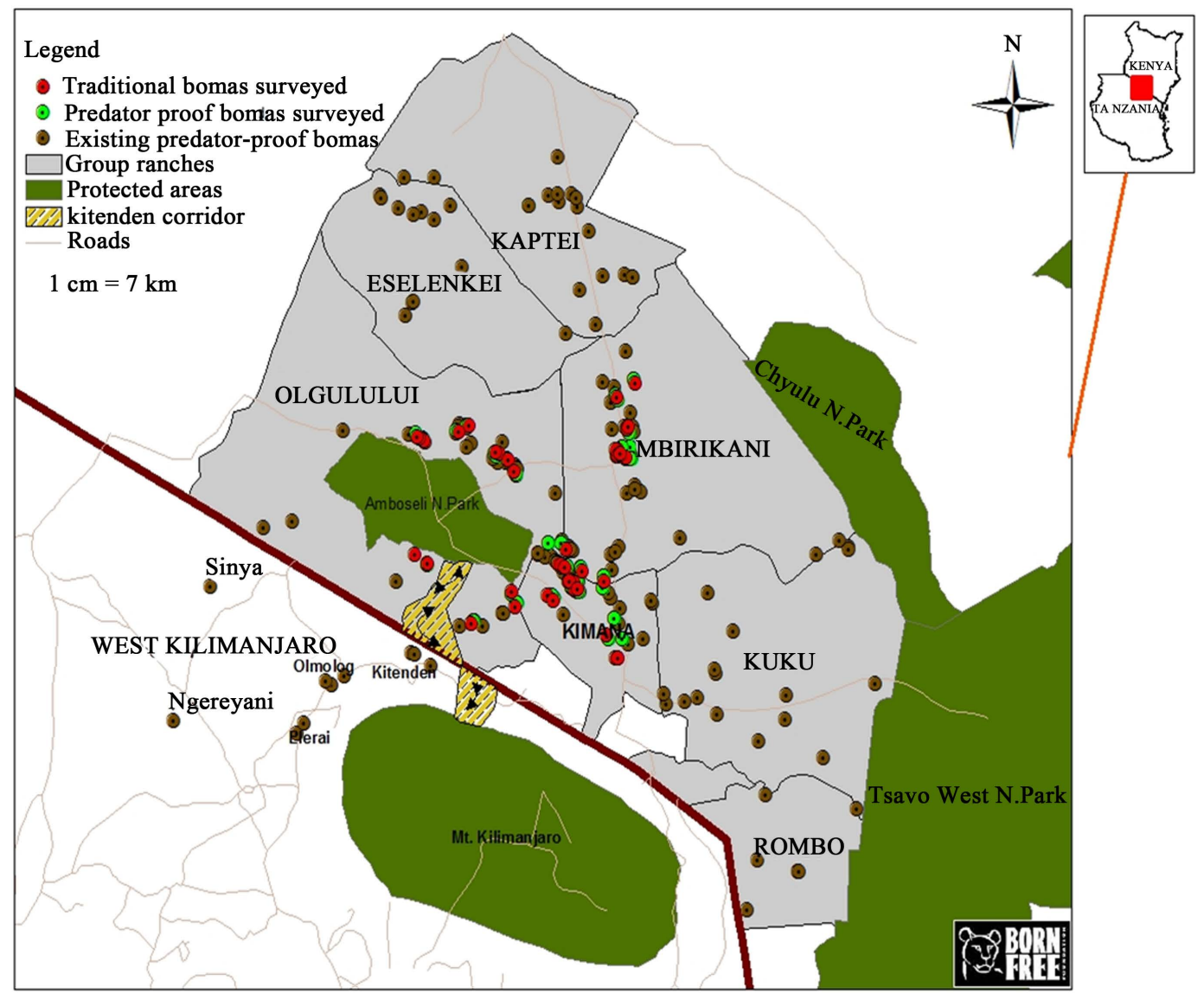

Figure 1. Map of the study area.

bomas, we concentrated on MGR, OGR and KGR/Tikondo which had the highest number of chain-link fenced bomas that had been in existence for at least six months since fortification. This study dwelled on Maasai pastoralist who own bomas only. Random sampling method was used in selecting respondents from each cluster. The purpose of choosing this method was to avoid bias and ensuring a representative sample is selected. The sampling procedures used were as follows:

- Stage one: From the six clusters, elimination method was used to select three cluster-MGR, KGR/Tikondo and OGR. The selected clusters had at least 50\% of the PPBs having been in existence for more than six months.

- Stage two: All the homesteads in the three clusters that were picked were then awarded numerical 1 - 3 separately to form a sampling frame. Numbers were then assigned to households in three selected clusters. The numbers for each cluster were then written onto separate pieces of papers and folded. All the folded papers were thereafter put in a basket and thoroughly shaken to mix them up. Numbers were then drawn from the basket, one after another, until the sample size of 15 per cluster was reached. Using the paired experimental design, for every predator-proof boma sampled, a traditional boma (control) within a range of a kilometre (to avoid overlapping with the next PPB) was selected at random using the North, South, East and West directions. Using this procedure, a sample size of 90 was randomly obtained for the study.

- Stage three: The areas to be survey were first visited by the researchers and a permission to carry out the survey granted by the respective local leaders. Six locally trained enumerators were trained by the researcher on the objectives of the survey and the approach to be employed. The questionnaires was pre-tested in group ranches (Eselenkei and Rombo), outside the three selected study area to ensure that all questions are clear, and a final version prepared before sampling took place.

Primary data was gathered through a face-to-face interview using questionnaires, photographs and field measurements while secondary data was obtained from existing map of the area, predator-proof boma unpub- 
lished project reports, articles and magazines. Data from the respondents was collected using questionnaires which had precise and closed questions with a list of possible answers to each question, and a board and open questions giving respondents an opportunity to freely express their opinions. The questionnaire had four parts, the first designed to provide respondent's background and boma characteristics such as area of resident, gender and age categories, livestock numbers, size of households, location and type of boma. The second part sought information on the performance of the traditional bomas on livestock losses, and the third part had questions to determine the performance of the predator-proof bomas. The second and third sections examined the livestock losses both in the boma and in the field grazing, predators involved in the attacks, respondents rating of the boma types and frequency of livestock guarding at night. The fourth part had information on community's perception on human-predator conflicts. This section had questions pertaining mainly to the most problematic predators and seasonality of predations both in the boma and in the field while livestock are grazing.

The questionnaires were administered to the 90 respondents. Before beginning the interview, the general purpose of the study was explained to each willing respondent and the confidentially of their information assured. The homestead heads were targeted as the respondents but in case where they were absence, their wives or another permanent resident adult (above 18 years) were interviewed. Each enumerator, administered 5 questionnaires per day for a period of 3 days. In addition to the questionnaires the study included field measurements and observations. This involved the measurement of the circumferences of the boma, thickness and height of the boma wall using a $100 \mathrm{~m}$ length tape measure. The distance between the observed nearest habitats type that can conceal a predator was determined by pacing. The damaged parts of the boma were determined by observation and counting.

Data processing, tallying and analysis was done at Microsoft Excel-Pivot Tables software 2013 and SPSS statistical package version 20.0. Data on sample households characteristics were treated according to clusters: OGR, MGR and KGR. Correlation tests were used to determine relationships between characteristics among the three area and paired-students t-test used to test significance difference in traditional boma and predator-proof bomas characteristics. Other data on boma characteristics, performance of the boma on livestock losses and community perceptions on human-predator conflicts were analyzed by calculating means, percentages and frequencies. Where questions had alternative answers on a Likert scale (such as Agree, Disagree, Strongly Agree, Strongly Disagree and Don't Know) were tested using modes to evaluate the opinion of the community.

\section{Results and Discussion}

\subsection{Livestock Predation Patterns}

Livestock predation occurred both in the field and in traditional boma. However, on a comparative basis there were high livestock attacks occurred in the field when livestock were grazing than in the traditional boma (Table 1) These findings are similar to [24] study in Ngorongoro conservation area which revealed that most

Table 1. Livestock lost in the traditional bomas and in the field grazing.

\begin{tabular}{ccc}
\hline Type of predated livestock and the occurrence environment & Number (N) & Mean \pm S.E \\
\hline Shoat killed in traditional boma & 39 & $7.56 \pm 2.311$ \\
Shoat killed in the field grazing & 32 & $8.75 \pm 3.440$ \\
Shoat injured in traditional boma & 38 & $4.24 \pm 1.893$ \\
Shoat injured in the field grazing & 32 & $5.72 \pm 2.564$ \\
Cattle killed in traditional boma & 38 & $1.71 \pm 0.445$ \\
Cattle killed in field grazing & 32 & $2.03 \pm 0.772$ \\
Cattle injured in traditional boma & 38 & $1.08 \pm 0.332$ \\
Cattle Injured in the field grazing & 31 & $1.45 \pm 0.641$ \\
Donkeys killed in traditional boma & 38 & $0.05 \pm 0.037$ \\
Donkeys killed in the field grazing & 31 & $0.10 \pm 0.71$ \\
Donkeys injured in the traditional boma & 38 & $0.03 \pm 0.026$ \\
Donkey Injured in the field grazing & 31 & $0.06 \pm 0.65$ \\
\hline
\end{tabular}


(76.4\%) of livestock attacks occurred during the day when livestock were grazing away from the boma, compared to $23.6 \%$ of night time attacks at the boma. This study has shown that hyena accounted for the largest loss of shoats in traditional boma $(37 \%, \mathrm{n}=68)$, while lion was majorly responsible for the loss of cattle in boma $(34 \%, n=44)$. Cheetah killed more $(89 \%, n=9)$ shoats in the field, followed by leopard $(60 \%, n=5)$. Similarly, [24] found out that $23.2 \%$ of the livestock attacks were on cattle, $67.4 \%$ shoats, and $9.3 \%$ donkeys.

There was a positive relationship between the most problematic predator and total number of livestock $(\mathrm{r}=$ $0.319, \mathrm{n}=90, p=0.002)$, boma circumference $(\mathrm{r}=0.295, \mathrm{n}=90, p=0.005)$, number of traditional huts $(\mathrm{r}=$ $0.015, \mathrm{n}=90, p=0.892)$, numbers of gates around the boma $(\mathrm{r}=0.173, \mathrm{n}=90, p=0.103)$; and number of people in the boma ( $\mathrm{r}=0.140, \mathrm{n}=90, p=0.188)$. However, there was a negative correlation between the most problematic predator and height of the boma wall $(\mathrm{r}=-0.074, \mathrm{n}=90, p=0.491)$ and thickness of the boma wall $(r=-0.004, n=90, p=0.970)$. These results suggested that the boma characteristics influence the types of the problematic predator that attacks the boma. The hyena was the most problematic predator (68\%), taking mostly sheep and goats.

In Magadi area, [25] also found out that hyena was a significant species largely associated with shoats killings at $44.4 \%$ among the Maasai. A review of the predator compensation scheme in Imbirikani group ranch by [26] also showed that hyena was most involved in most predation incidences and associated with higher compensation costs, followed by jackal, cheetah, lion and leopard, with some deaths by buffalo attacks. This study findings also resembles [27] study in Maasai Steppe in Tanzania, where lions mostly preyed upon adult cattle and donkeys, while hyenas and leopards primary killed small stock (goat, sheep and calves) and dogs. In another survey carried out by [28] around Serengeti National park in Tanzania, livestock depredation was reported to be caused most often by spotted hyena (97.7\%), leopard (1.6\%), baboon (0.4\%), lion (0.1\%) and lastly blackbacked jackal $(0.1 \%)$. The high depredation on shoats can be attributed to their high numbers per boma compared to cattle and donkeys (Table 2).

The high killings of shoats by hyena, cheetah and leopards could be as result of their smaller size and can be quickly be picked perhaps without the predators using more energy compared to cattle and donkeys. In addition, their smaller body size could mean they are more vulnerable and likely to succumb to injuries from the predators.

The study established that rocky, shrub and swamp habitats distances from the traditional boma had positive relationships with the predators that killed livestock. Rock habitat distance had an effect on both cattle killed $(\mathrm{r}=$ $0.450, \mathrm{n}=27, p=0.191)$ and shoat killed $(\mathrm{r}=0.176, \mathrm{n}=14, p=0.546)$ while shrub and swamp had positive relationship with predators that killed shoats. These finding related to [19] finding in the Amboseli-West Kilimanjaro landscape, where distances from abandoned bomas and distance to water sources greatly influenced the distribution of spotted hyena, lion and black jackal. [19] study further revealed that vegetation cover contributed $40.1 \%$ of the influence on spotted hyena distribution, $48.1 \%$ of black-backed jackals' distribution, and $18.1 \%$ of lion's distribution. Open grasslands with sparse shrubs, open grasslands and sparse grasslands had the greatest contribution indicating that all three carnivore species were more likely to be found in these types of vegetation. The study found that the optimum distance that hyena and jackal would be found from human settlement was 5 kilometres. Therefore, human settlements and habitat type influence the distributions of predators, and the distribution determines the predation on livestock.

Table 2. Livestock attacks by different predators.

\begin{tabular}{ccccccccccc}
\hline \multirow{2}{*}{ Type of predator } & \multicolumn{2}{c}{ Traditional boma incidences } & \multicolumn{2}{c}{ Grazing field incidences } & \multicolumn{3}{c}{ Predator-proof boma incidences } \\
\cline { 2 - 11 } & Shoat & Cattle & Donkey & Shoat & Cattle & Donkey & Shoat & Cattle & Donkey & Total \\
\hline Lion & $25 \%$ & $34 \%$ & $2 \%$ & $7 \%$ & $25 \%$ & $0 \%$ & $2 \%$ & $5 \%$ & $0 \%$ & $\mathbf{1 0 0 \%}$ \\
Hyena & $37 \%$ & $16 \%$ & $1 \%$ & $24 \%$ & $13 \%$ & $3 \%$ & $4 \%$ & $1 \%$ & $0 \%$ & $\mathbf{1 0 0 \%}$ \\
Cheetah & $11 \%$ & $0 \%$ & $0 \%$ & $89 \%$ & $0 \%$ & $0 \%$ & $0 \%$ & $0 \%$ & $0 \%$ & $\mathbf{1 0 0 \%}$ \\
Leopard & $20 \%$ & $20 \%$ & $0 \%$ & $60 \%$ & $0 \%$ & $0 \%$ & $0 \%$ & $0 \%$ & $0 \%$ & $\mathbf{1 0 0 \%}$ \\
Jackal & $0 \%$ & $0 \%$ & $0 \%$ & $0 \%$ & $0 \%$ & $0 \%$ & $0 \%$ & $0 \%$ & $0 \%$ & $\mathbf{0} \%$ \\
Total & $\mathbf{3 0} \%$ & $\mathbf{2 1 \%}$ & $\mathbf{2 \%}$ & $\mathbf{2 4 \%}$ & $\mathbf{1 6 \%}$ & $\mathbf{2 \%}$ & $\mathbf{3 \%}$ & $\mathbf{2 \%}$ & $\mathbf{0 \%}$ & $\mathbf{1 0 0 \%}$ \\
\hline
\end{tabular}




\subsection{Seasonality of Attacks}

Seasonality of livestock attacks in the field and in the boma varied. The months of April and December on average had high predation incidents in bomas, while September and October registered high field predation incidents (Figure 2).

A regression analysis indicates that there was a positive significant relationship between frequencies of livestock attacks in the field and the time of the year $\left(\mathrm{r}^{2}=0.5407, \mathrm{n}=90, p<0.05\right)$. The Loitokitok sub-county, where the Amboseli ecosystem is located experiences a bimodal rainfall pattern. The short rains falls between October and December while the long rains fall between March and May [21]. According to [29], stochastic weather patterns can force wide-ranging species beyond current reserve boundaries, into areas where there will be greater conflicts with humans. [27] studies in Maasai Steppe in Tanzania revealed that livestock predation by lions and hyenas were more prevalent in the wet season while leopard attacks did not differ between seasons.

The high livestock predation during the rain seasons can be attributed to the wet-season migration of wild prey from protected areas onto communal village land. The predators are then expected to follow the herbivore, and since there is enough pasture and water, it may require the predators to use more energy to capture the prey. In this case, livestock becomes an alternative "easy" prey for the predators. This study findings were different from those of [25], whose results revealed that general human-wildlife were more in dry season than wet season in Magadi. The difference could be as result of this study having specifically focused on livestock predation rather than crop raiding, destructive of facilities and livestock predation combined in relation to seasons.

\subsection{Comparison of Traditional and Predator-Proof Boma Characteristics}

Predator-proof bomas had either wooden or recycled plastic posts (2.4 m long), flattened oil drums gates and rolls of chain-links $(1.84 \mathrm{~m})$. On average the predator-proof bomas were larger in circumferences $(149.5 \mathrm{~m})$ than the traditional bomas (128.3) and had more livestock (293.2). However, in terms wall thickness, numbers of traditional huts, gates and height of walls were almost the same. The presence of more livestock in the predator-proof boma could be as result of the additional strong posts, rolls of chain-links and metal doors that provided an additional protection to livestock at night than the traditional bomas, encouraging community to stock more livestock in the predator-proof bomas. Table 3 shows the general characteristics of the bomas.

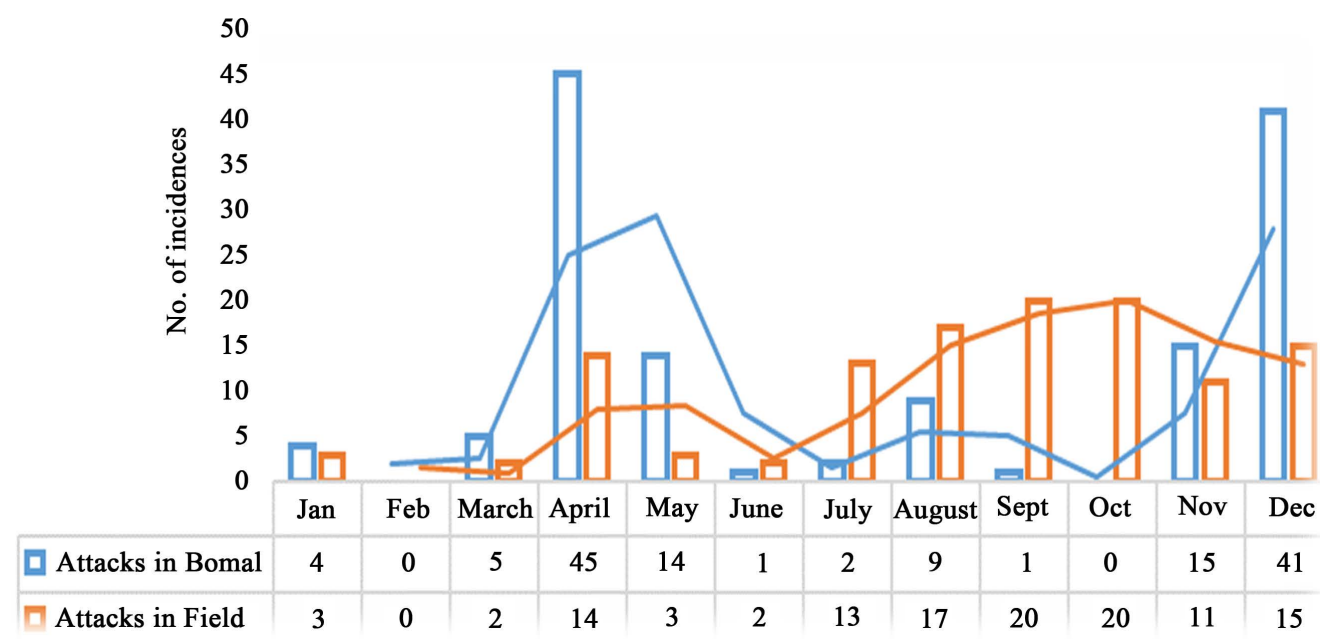

Figure 2. Seasonality of livestock attacks.

Table 3. Comparison of PPB and traditional boma characteristics.

\begin{tabular}{|c|c|c|c|c|c|c|c|}
\hline Boma Type & Circumference (m) & $\begin{array}{l}\text { Height of } \\
\text { wall(m) }\end{array}$ & $\begin{array}{c}\text { Thickness } \\
\text { of fence (m) }\end{array}$ & $\begin{array}{l}\text { No. of } \\
\text { traditional huts }\end{array}$ & $\begin{array}{l}\text { No. of entrances } \\
\text { around boma }\end{array}$ & $\begin{array}{c}\text { No. } \\
\text { of people }\end{array}$ & $\begin{array}{c}\text { No. } \\
\text { livestock }\end{array}$ \\
\hline Predator-proof boma & 149.5 & 2.16 & 1.34 & 4.98 & 2.18 & 20.5 & 293.2 \\
\hline Traditional boma & 128.3 & 1.93 & 1.31 & 5.08 & 2.04 & 20.3 & 191.9 \\
\hline
\end{tabular}


This study found a positive relationship between the boma characteristics and livestock predations. The boma that were larger had more people, livestock, gates and high livestock attacks. These findings support. [30] study in Elerai and Oltiyiani conservancies in Amboseli, in which homestead size, number of livestock (cattle, shoats and donkeys) and human demographics all had a positive correlation with livestock killed. [4] in a study undertaken around Ruaha National park in Tanzania also showed that boma characteristics were important in reducing the predator attacks, with larger bomas that had more livestock and external entrances having high attacks. Several external entrances were seen as being a risk factor as they could be weak points of entry into the bomas. However, this study findings are contrarily to [24] results in Ngorongoro which indicated that the only factor consistently related to livestock attack rate was the number of people living at the homestead $(r=-0.62, n=15$, $p=0.015$ ) with the smaller bomas being more vulnerable to livestock loss. Also [31] studies in Laikipia on commercial and community ranches detected no effect of the thickness, height or complexity of boma walls on the rate of livestock loss. [31] compared livestock loss in different bomas and found that wire enclosures provided the least protection from predators, with up to five times the depredation rate in traditional bomas.

The hypothesis testing relationship between livestock predation and boma characteristics found significant differences in the characteristics of the traditional boma and predator-proof bomas with absolute values of size ( $\mathrm{t}$ $=2.504$, d.f $=44, p=0.016)$, height of fence $(\mathrm{t}=-2.379$, $\mathrm{d} . \mathrm{f}=44, p=0.022)$, and total number of livestock $(\mathrm{t}=$ -2.253 , d.f $=44, p=0.029$ ) all being greater than the critical value, $\mathrm{t}=2.015$ (Table 4). The size, height and total number of livestock had significant differences. However, numbers of gates, people and traditional huts in PPB and traditional bomas were all similar $(p>0.05)$.

\subsection{Performance of Predator-Proof Bomas on Livestock Predation}

The predator-proof bomas resulted to the reduction in livestock predation incidences in the boma at night. The findings showed that $91.11 \% \mathrm{n}=45$ ) had not lost their livestock to predators at night in the boma since their bomas were fortified. $62 \%(n=45)$ and $31 \%(n=45)$ of the respondents rated the predator-proof boma to be "Excellent" and "Good" in reducing livestock attacks at night respectively. These findings supports those of [32] study in Maasai Steppe in the eastern side of Tarangire National park in Tanzania, where fortification of bomas resulted in the reduction of livestock predation by $90 \%$, only two incidences of livestock depredation being reported. In both attacks, leopard entered through a faulty gate and killed two shoats.

The time spent guarding livestock on daily basis also reduced significantly with only two people still guarding their boma daily per week (Table 5). The reduction in vigilance time at night have several positive implications: the community members can now be active during the day and participate in other social and economic activities, reduced chances of individuals being bitten by insects such as mosquitoes and scorpions, which can have a detrimental effect on one's health, families can also have an opportunity to sit together and bond in the evening and couples have a chance to share their matrimonial bed together and enhance their relationship.

The community considered the predator-proof boma to be cost effective (Good $=44 \%$ and Average $=40 \%$ ). However, the rating on the durability of the structure on aggregate (Average, Poor and very poor) was on average low (Table 6). This can be explained by the fact that some of the sampled bomas were built using wooden posts that had been chewed by termites reducing the durability of the boma structure. On the other hand, cost effectiveness high ratings can be attributed to the cost sharing nature of the project, where the community makes a one-time contribution of $25 \%$ of the overall cost of construction.

\begin{tabular}{|c|c|c|c|c|}
\hline Boma characteristics & t-test value & d.f & Sig. (2-tailed) & Remarks \\
\hline Size (Circumference) & -2.504 & 44 & $P=0.016$ & Significant \\
\hline Height of the fence & -2.379 & 44 & $P=0.022$ & Significant \\
\hline No. of gate around the boma & -0.643 & 44 & $P=0.524$ & Not significant \\
\hline Total No. of people in boma & -0.053 & 44 & $P=0.958$ & Not significant \\
\hline Total No. of livestock in boma & -2.253 & 44 & $P=0.029$ & Significant \\
\hline No. of traditional huts in the boma & 0.180 & 44 & $P=0.858$ & Not significant \\
\hline
\end{tabular}


Table 5. Guarding frequency with and without the predator-proof boma (PPB).

\begin{tabular}{ccc}
\hline Livestock guarding frequency per week & Without PPB & With PPB \\
\hline Once & $4 \%$ & $40 \%$ \\
Twice & $9 \%$ & $29 \%$ \\
Thrice & $2 \%$ & $4 \%$ \\
Four times & $2 \%$ & $0 \%$ \\
Five time & $0 \%$ & $2 \%$ \\
Six times & $2 \%$ & $4 \%$ \\
\hline
\end{tabular}

Table 6. Rating of predator-proof boma (PPB) by households.

\begin{tabular}{|c|c|c|c|c|c|c|c|}
\hline \multirow{2}{*}{$\begin{array}{c}\text { Priority benefits } \\
\text { Reducing livestock predations }\end{array}$} & \multicolumn{7}{|c|}{ Percentage ratings according to PPB users } \\
\hline & Excellent & Good & Average & Poor & Very poor & Don't know & Total \\
\hline $\begin{array}{l}\text { Reducing retaliatory killings } \\
\text { of predators especially lions }\end{array}$ & $62 \%$ & $31 \%$ & $7 \%$ & $0 \%$ & $0 \%$ & $0 \%$ & $100 \%$ \\
\hline $\begin{array}{l}\text { Minimising night vigilance of livestock } \\
\text { and offering alternative time for engaging } \\
\text { in other social and economic activities }\end{array}$ & $38 \%$ & $56 \%$ & $7 \%$ & $0 \%$ & $0 \%$ & $0 \%$ & $100 \%$ \\
\hline Cost effectiveness & $13 \%$ & $47 \%$ & $40 \%$ & $0 \%$ & $0 \%$ & $0 \%$ & $100 \%$ \\
\hline Durability of the structure & $4 \%$ & $29 \%$ & $38 \%$ & $24 \%$ & $4 \%$ & $0 \%$ & $100 \%$ \\
\hline
\end{tabular}

\subsection{Effects of Predator-Proof Bomas on Community Livelihood}

The predator-proof bomas resulted to the reduction in livestock loss and time spend guarding livestock at night. Based on the average livestock market prices at Kimana (4 ${ }^{\text {th }}$ May, 2015) of sheep \& goat (Ksh 5000 each), donkey (Ksh 10,000) and cattle (Ksh 20,000), it implies that households had lost Ks 3,225,000 compared to Ksh 195,000 lost after boma fortification. MacLennan et al. (2009) study on the Mbirikani Group Ranch Amboseli showed that predators took 2.28\% of the livestock herd annually. [30] found out that Big Life Foundation spent more than Kenya shillings 28 million on compensation for over 9000 livestock killed in bomas only. Livestock remains the main asset that pastoralist can own/ control and can be sold to meet emergency and family health and education needs. In times of food shortages, households sell livestock to purchase other food such as cereals and legumes. Livestock and livestock products are consumed and provide protein diet for households. It is for these reasons, that a single loss of stock can elicit a much stronger emotional response from owners.

[33] asserts that an ideal tools for reducing depredation should benefit both farmers and wildlife conservation and outlines its desirable features as, persistent efficacy, minimal unintended environmental consequences, selectivity towards problematic individuals, lower cost than that of the depredation prevented, and social acceptability. This study results suggest that predator-proof boma can efficiently and cost-effectively reduce depredation on domestic stock by reducing the economic cost of livestock depredation by carnivores.

\subsection{Community Attitudes and Perceptions on the Most Problematic Predator}

Hyena was cited as the most problematic predator (68\%). Community living near the park and conservancies (26\%), their growing population (16\%) and their predation on livestock (12\%) were the major reasons for predator being problematic. [26] reviewed the data of compensation scheme of the Big Life Foundation, and found out that hyena were the major predators targeting all livestock types, while lions primary targeted cattle. When asked about their opinions on the most problematic predator, majority showed a positive tolerance to the protection of predator (73\%), predator's role in revenue generation through tourism (67\%) and their importance in maintaining a healthy environment (66\%). However, on aggregate (Agree and Strongly Agree) a considerable 
proportion of 38\% were against sparing a predator that kill livestock. In [34] study in Imbirikani group ranch in Amboseli, 4.0\% of respondents indicated nothing would stop them from killing a carnivore which had attacked/ killed their livestock regardless of knowing there is a law in Kenya against killing carnivores. In other study conducted in Ewaso ecosystem in Samburu in 2010, [35] found out that community members were less enthused about the presence of predators, with only about $20 \%$ wanted to have spotted hyenas on their land, and about $40 \%$ wanted to have other predator species. [35], argued that community members were more likely to want predators on their land if benefits from having predators reached the individual, not if benefits were only given to the community as a whole. These results suggest that strategies aimed to reduce livestock predation should be increased in addition to conservation efforts that focuses on increasing the spread of wildlife benefits revenue generated and community awareness on the importance of predators.

\section{Conclusions and Recommendations}

In conclusion, our study findings suggest that predator-proof bomas are effective in reducing livestock predation at night. However, the effectiveness of the boma is largely depending on the size, livestock numbers, number of entrances to the boma and the type of predator that challenges the boma. The predator-proof bomas have also proved to be a highly valued mitigation measure by the respondents. Of importance is the maintenance aspect to avoid creating avenue for predator entry into fortified bomas. A change in herding practices can reduce livestock loss in fields and hence supplement the predator-proof boma project effects. Human-carnivore conflicts are a regular occurrence in Amboseli homesteads, with predation problem on livestock being more pronounced in the field than in the traditional bomas.

Although several species of predators are involved in the livestock loss, hyenas are singled out as the most problematic predator, disliked by the respondents. This can be attributed to its nature of attacks and the number of livestock losses it causes at a go. The respondents are averagely tolerant to the predators. The small proportion that thought otherwise should be given more attention to deter any possible retaliatory killings of the predators. Promoting positive attitudes to predators and helping individuals to understand the value of predator in the landscape could still be necessary to reduce human-predator conflict in Amboseli, particularly as predators not only attack households at night, but also livestock grazing in the field. Depredation can result to considerable losses for individuals, and some pastoralists may continue to harbor negative attitudes towards carnivores despite the existence of fortified bomas.

The livestock predation results to both social and economic losses to the community. The findings of this study suggest that conflicts could be significantly be reduced by improving husbandry practices. Therefore, human-wildlife conflict mitigation project should not only minimize conflicts, but also enhance the livelihood of the beneficiaries. The predator-proof bomas are larger than the traditional bomas. This is as result of PPBs providing safety for livestock at night and reducing livestock predations at night. The study also demonstrates that the larger the boma, the more attacks it is likely to have. Larger bomas had more entrances, more livestock and people. More gates are expected to be easy entry points for predators and high number of livestock reduces the durability of the bomas structure. However, the presence of more people was contrarily to the expectations, that more people would be an additional security. Therefore, it is the structure of the boma that determine the predation incidences and not the attentiveness and number of people in it.

Based on the findings, it is recommended that awareness campaigns should be carried out to encourage the community to keep vigilance of livestock during grazing in the field to avoid predation during the day. The livestock should also be returned home early enough and counted, so that any lost livestock in the bush can immediately be searched before dark. The construction and maintenance of the predator-proof boma should be encouraged as a long term solution to livestock loss at night and regular maintenance is done for durability of the structure.

\section{References}

[1] Mayaka, T.B. (2002) Value Wildlife! An Ecological and Economic Assessment of Wildlife Use in Northern Cameroon. Dissertation. Wageningen University, Wageningen.

[2] Berger, L.R. and Clarke, R.J. (1995) Eagle Involvement in the Accumulation of the Taung Child. Journal of Human Evolution, 29, 275-299. http://dx.doi.org/10.1006/jhev.1995.1060

[3] Messmer, T.A. (2000) Emergence of Human-Wildlife Conflict Management: Turning Challenges into Opportunities. 
International Biodeterioration, 45, 97-100. http://dx.doi.org/10.1016/s0964-8305(00)00045-7

Messmer, T.A., George, S. and Cornicelli, L. (1997) Legal Considerations Regarding Lethal and Nonlethal Approaches to Managing Urban Deer. Wildlife Society Bulletin, 25, 424-429.

[4] Dickman, J.A. (2008) Key Determinants of Conflict between People and Wildlife Particularly Large Carnivores, a Round Ruaha National Park, Tanzania. Ph.D. Thesis, University College London and Institute of Zoology, Zoological Society of London.

[5] Hoffman, T.S. and O’Riain, M.J. (2012) Monkey Management: Using Spatial Ecology to Understand the Extent and Severity of Human-Baboon Conflict in the Cape Peninsula, South Africa. Ecology and Society, 17, 13. http://dx.doi.org/10.5751/ES-04882-170313

[6] Marchini, S. (2014) Who's in Conflict with Whom? Human Dimension of the Conflict Involving Wildlife. In: Verdade, L.M., Lyra-Jorge, M.C. and Piña, C.I., Eds., Applied Ecology and Human Dimension in Biological Conservation, Springer-Verlag, Berlin, 189-190.

[7] Barlow, A.C.D. (2009) The Sundarbans Tiger: Adaptation, Population Status, and Conflict Management. Ph.D. Thesis, University of Minnesota, Minnesota. http://www.carnivoreconservation.org/files/thesis/barlow_2009_phd.pdf

[8] Worthy, R.F. and Foggin, M.J. (2008) Conflicts between Local Villagers and Tibetan Brown Bear Threaten Conservation of Bears in a Remote Region of the Tibetan Plateau. Human-Wildlife Interaction, Paper 59.

http://digitalcommons.unl.edu/cgi/viewcontent.cgi?article=1058\&context=hwi

[9] Storm, D.J., Nielson, C.K., Shauber, E.M. and Woolf, A. (2007) Deer-Human Conflict and Hunter Access in an Exurban Landscape. Human-Wildlife Interactions, Paper 133.

[10] Brook, R.K. (2009) Historical Review of Elk-Agriculture Conflicts in an around Riding Mountain National Park, Manitoba, Canada. Human-Wildlife Interaction, 21. http://digitalcommons.unl.edu/hwi/21

[11] Lamarque, F., Anderson, J., Fergusson, R., Lagrange, M., Osei-Owusu, Y. and Bakker, L. (2009) Human-Wildlife Conflict in Africa: Causes, Consequences and Management Strategies. Food and Agriculture Organization of the United Nations, Rome, p. 112.

[12] FAO (2010) Managing the Conflict between People and Lion, Review and Insights from the Literature and Field Experience. Wildlife Management Working Paper 13, 16.

[13] Rigg, R., Slavomir, R., Maria, W., Martyn, L.G., Sillero-Zubiri, C. and David, W.M. (2011) Mitigating Carnivore-Livestock Conflict in Europe: Lessons from Slovakia. Oryx, 45, 272-280. http://dx.doi.org/10.1017/S0030605310000074

[14] Sapkota, S., Aryal, A., BARAL, R.S., Hayward, W.M. and Raubenheimer, D. (2014) Economic Analysis of Electric fencing for Mitigating Human-Wildlife Conflict in Nepal. Journal of Resource and Ecology, 5, 273-243. http://dx.doi.org/10.5814/j.issn.1674-764x.2014.03.006

[15] Ferraro, P.J. and Pattanayak, S.K. (2006) Money for Nothing? A Call for Empirical Evaluation of Biodiversity Conservation Investments. PLoS Biology, 4, e105. http://journals.plos.org/plosbiology/article?id=10.1371/journal.pbio.0040105 http://dx.doi.org/10.1371/journal.pbio.0040105

[16] James, A.N., Edgar, D. and Taylor, S. (1999) Balancing the World’s Accounts. Nature, 401, 323-324. http://dx.doi.org/10.1038/43774

[17] Okello, M.M. and Kioko, J.M. (2010) Contraction of Wildlife Dispersal Area in Olgulului-Ololorashi Group Ranch around Amboseli National Park, Kenya. The Open Conservation Biology Journal, 4, 34-45.

[18] Esikuri, E.E. (1998) Spatio-Temporal Effects of Land Use Changes in a Savanna Wildlife Area of Kenya. Ph.D. Thesis, Virginia Polytechnic Institute and State University, Blacksburg.

[19] Kissui, B. and Kenana, L. (2013) Amboseli-West Kilimanjaro Large Carnivore Census Report, 2013.

[20] Pratt, D.J. and Gwynne, M.D. (Eds.) (1977) Rangeland Management and Ecology in East Africa. Hodder \& Stoughton, London-Sydney-Auckland-Toronto.

[21] GoK (2009) Kajiado District Environment Action Plan 2009-2013.

[22] KWS (2008) Amboseli Ecosystem Management Plan, 2008-2018.

[23] BFF (2014) Lion-Proof Boma. http://www.bornfree.org.uk/animals/lions/projects/lion-proof-bomas/

[24] Ikanda, D. and Packer, C. (2008) Ritual vs. Retaliatory Killing of African Lions in the Ngorongoro Conservation Area, Tanzania. Endangered Species Research, 6, 67-74. http://dx.doi.org/10.3354/esr00120

[25] Mwathe, K.M. (2007) The Nature, Economic Costs and Management Strategies for Human Wildlife Conflict in Magadi Area, South Rift Kenya. Master's Thesis, University of Nairobi, Nairobi.

[26] Okello, M.M., Bonham, R. and Hill, T. (2014) The Pattern and Cost of Carnivore Predation on Livestock in Maasai 
Homesteads of Amboseli Ecosystem, Kenya: Insights from a Carnivore Compensation Programme. International Journal of Biodiversity and Conservation, 6, 502-521. http://dx.doi.org/10.5897/IJBC2014.0678

[27] Kissui, B.M. (2008) Livestock Predation by Lions, Leopards, Spotted Hyenas and Their Vulnerability to Retaliatory Killing in the Maasai Steppe, Tanzania. Animal Conservation, 11, 422-432. http://dx.doi.org/10.1111/j.1469-1795.2008.00199.x

[28] Holmern, T., Nyahongo, J. and Røskaft, T. (2007) Livestock Loss Caused by Predators Outside the Serengeti National Park, Tanzania. Biological Conservation, 135, 534-542. http://dx.doi.org/10.1016/j.biocon.2006.10.049

[29] Tuqa, J.H., Funston, P., Ojwang, O.G., Gichuki, N.N., Bauer, H., Tamis, W., Dolrenry, S., Van’t Zelfde, M., de Snoo, G.R. and de Long, H.H. (2014) Impact of Severe Climate Variability on Lion Home Range and Movement Patterns in the Amboseli Ecosystem, Kenya. Global Ecology and Conservation, 2, 1-10. http://www.journals.elsevier.com/global-ecology-and-conservation

[30] Okello, M.M., Kiringe, W.J. and Warinwa, F. (2014) Human-Carnivore Conflicts in Private Conservancy Lands of Elerai and Oltiyiani in Amboseli Area, Kenya. Natural Resources, 5, 375-391. https://www.awf.org/sites/default/files/media/Resources/Books\%20and\%20Papers/Okello,\%20Kiringe\%20and\%20Fie sta\%202014.pdf http://dx.doi.org/10.4236/nr.2014.58036

[31] Ogada, M., Woodroffe, R., Oguge, O.N. and Frank, G.L. (2003) Limiting Depredation by African Carnivores: The Role of Livestock Husbandry. Conservation Biology, 17, 1521-1530. http://dx.doi.org/10.1111/j.1523-1739.2003.00061.x

[32] Lichtenfeld, L.L., Trout, C. and Kisimir, L.E. (2015) Evidence-Based Conservation: Predator-Proof Bomas Protect Livestock and Lions. Biodiversity and Conservation, 24, 483-491. http://dx.doi.org/10.1007/s10531-014-0828-X

[33] Mcmanus, J.S., Dickman, A.J., Gaynor, D., Smuts, B.H. and Macdonald, D.W. (2014) Dead or Alive? Comparing Costs and Benefits of Lethal and Non-Lethal Human-Wildlife Conflict Mitigation on Livestock Farms. Oryx, 49, 687-695. http://journals.cambridge.org

[34] Shari, L.R. (2007) Perceptions and Attitudes of a Maasai Community in Southern Kenya Regarding Predator-Damage Compensation, Wildlife Conservation and the Predators That Prey on Their Livestock. A Capstone Paper Submitted in Partial Fulfillment of the Requirements for a Master of Sustainable Development at the School for International Training in Brattleboro.

[35] Stephanie, S.R., Lindsey, A.P. and Woodroffe, R. (2010) Attitudes toward Predators and Options for Their Conservation in the Ewaso Ecosystem. Smithsonian Contributions to Zoology, No. 632, 85-93. http://www.princeton.edu/ dir/pdf dir/2011 Laikipia \%20Landscape \%20Planning \%20Model.pdf 